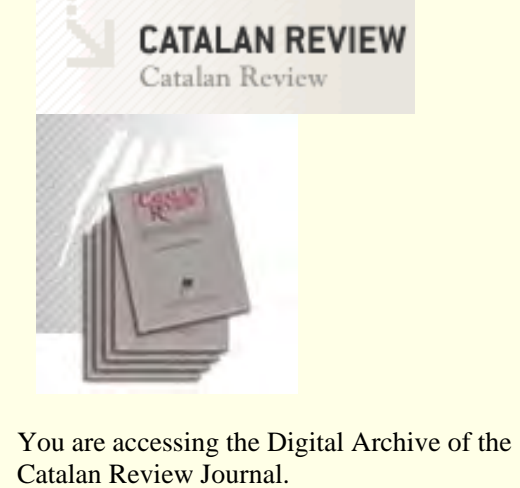

Catalan Review Journal.

By accessing and/or using this Digital Archive, you accept and agree to abide by the Terms and Conditions of Use available at http://www.nacs-

catalanstudies.org/catalan_review.html

Catalan Review is the premier international scholarly journal devoted to all aspects of Catalan culture. By Catalan culture is understood all manifestations of intellectual and artistic life produced in the Catalan language or in the geographical areas where Catalan is spoken. Catalan Review has been in publication since 1986 .
NORTH

AMERICAN

CATALAN

SOCIETY
Esteu accedint a l'Arxiu Digital del Catalan Review

A l' accedir i / o utilitzar aquest Arxiu Digital, vostè accepta i es compromet a complir els termes i condicions d'ús disponibles a http://www.nacs-

catalanstudies.org/catalan_review.html

Catalan Review és la primera revista internacional dedicada a tots els aspectes de la cultura catalana. Per la cultura catalana s'entén totes les manifestacions de la vida intel lectual i artística produïda en llengua catalana o en les zones geogràfiques on es parla català. Catalan Review es publica des de 1986.

\title{
Linguistic recruitment and linguistic defection in Catalonia: an overview Paul E. O'Donnell
}

Catalan Review, Vol. V, number 2 (December, 1991), p. 97-105 


\section{LINGUISTIC RECRUITMENT AND LINGUISTIC DEFECTION IN CATALONIA: AN OVERVIEW'}

\section{PAUL E. O'DONNELL}

In other forums (e.g. O'Donnell 1989 , I990), 1 have stated that most analysts of the Catalan sociolinguistic situation have clear, or only slightly camouflaged, political agendas. The plethora of studies and surveys provides a wide array of ufacts" and statistics that we can tailor to fit the desired conclusions. This introduction might lead the reader to believe that any researcher can pose as an unbiased outside observer of the linguistic conflict in Catalonia. However, two terms used in the title and body of this text, recruitment and defection, cannot be interpreted as neutral, objective designations for ongoing processes in the Catalan-Castilian dichotomy.

In the linguistic dispute between Castilian and Catalan, the terms recruitment and defection clearly refer to the Catalan side gaining or losing numbers. In the face of centuries-long Castilian linguistic hegemony, Catalan, like other minority languages, is clearly the one that needs widespread and aggressive "affirmative actionn to hold its own and to flourish against the powerful opponent-language. The tactics examined herein involve recruiting, and actively "Catalanizing", potential linguistic defectors from the castellanoparlante band.

In the interests of brevity, this study leaves aside definitions of levels of recruitment, the ethnolinguistic terms Castilian and Catalan ${ }^{2}$, and the huge body of research that makes manifest the

'A modified version of this article was presented at he Modern Languages Association Convention 1990; Chicago, Illinois, U.S.A.

${ }^{2}$ Woolard (1989:42) expresses the distinction between Castilian and Catalan in the following way; «The most commonly-used term for non-Catalan identity is "Castilian" (castellà, "castellano"), used by Catalans and Castilians alike."

References to catalans as people who speak Catalan and associate with 
need for Castilian group members joining the Catalan speaking camp. Suffice it to say about the last point -the need for recruits- that the most recent information I have received from Barcelona shows that Castilian immigrant birthrates are twice as high as non-migrating birthrates (Sarrabile 1987 , and Strubell I990, personal communication). Therefore, even a maintenance of Catalan use among all native-born Catalans (many of whom are from Castilian-dominant households) would lead to a steady decline of Catalan use in the Principat. While there are statistics that show Catalan as strong, alive, and understood by almost $93 \%$ of residents of Catalonia, statistics on actual use are less encouraging.

From my research on linguistically «mixed» families in Catalonia, I clearly concluded that not only is recruitment necessary, it exists de facto in every locality large enough and diverse enough to have contact between the ethnolinguistic groups. What started out as a two-month study on the borders of Greater Barcelona (1989) has become an ongoing survey: Since my urecruitment tactics" project began, I have received a steady stream of correspondence. Emanating from recruits, would-be recruits, and semi-inductees from the Castilian camp, the mail relates the successes and sorrows in trying to join the Catalan «club». My work involved sorting, categorizing, and placing on a map those patterns of recruitment which had the highest success rate.

For participants in the linguistic policy debate, the concept of recruitment may not represent a viable option. Herein I shall review a few of the most salient perspectives that find their ways

other Catalans are common in the Barcelona metropolitan area. A castellà is a non-Catalan speaker or a bilingual of non-Catalan origin who associates mostly with Spanish speakers. However, when a Castilian-speaking resident of Catalonia visits his native (non-Catalan) pueblo, he or she may be called uel catalann or «la catalanam. The connotations and implications of these two terms (or their equivalents in either language) are endless. However, when a nationalistic Catalan calls someone an espanyol, the negative connotations cannot be denied. Often, Catalans identify themselves by what they are not: uno som espanyolss. 
into scholarly journals and into the daily press in Catalonia. J. M. Sobrer (1990) maintains that defining Catalonia is the initial problem, since it could refer to the autonomous entity within the Spanish state, or the Països Catalans (or "Catalan Lands"), that includes a much greater geographical scope.

According to Sobrer (I990), two paths await the minority language in a plurilingual society: That of creolization and that of language separation (or «mythicization»). Sobrer's comments run parallel to those of certain language commentators in Catalonia. For Modest Prats, a Catalan author and professor, the risks of officialized bilingualism are several. First, we go against the general flow of history in attempting to manage a bilingual society such that one language does not dominate and destroy the other. Second, there exists the danger of «Latinization of Catalan', as Prats (interviewed in Caranch r990:A) calls it. Catalan now evolves along two paths, one "Classical», one "Vulgan. The two have already developed two registers (written and colloquial) that continue to diverge. Like Sobrer, Prats sees mythicization as a partial solution, for without clear authority on "correct» Catalan, the "high" and «low» registers will continue to differentiate. One of the lightning rods for attacks on language matters in Catalonia has been Ricard Fité, who served as linguistic advisor to Catalunya Radio, a Catalan language radio network. Accused of «hispanizing» Catalan and promoting a dialect called "hispano-barcelonín Fité claims (quoted in Caranch 1990: I) he merely attempted to create a simple lexicon that fits the everyday language of the radio listener. Furthermore, he claims that audio-visual media have actually been more successful than the written word in preventing language loss. Thus, for Fité, this situation does not appear so bleak, and use of common Catalan promotes, rather than degrades, the spread of Catalan.

One of the most strident voices in the public policy debate over Catalan is that of Ferran Toutain, co-author of a book about the lack of reasonable standards for spoken and written Catalan. For this author (quoted in Caranch I990:1 5) «the basic problem 
of Catalan is that everyone from the school teachers to the university professors and the writers, all the important elements of our culture, are half-illiterate when it comes to using the language». He claims that if we cannot do something to improve Catalan, then no Catalan is better than a mediocre language. Furthermore, he prefers mercy killing rather than slow death for the language. This position in favor of euthanasia represents the «alarmist» wing of the policy debate.

Thus, the question of ethnolinguistic recruitment to Catalan remains clouded by several questions: Recruitment to which kind of Catalan speech, to which kind of Catalan society, and by whom? For Toutain, integration into a watered-down, descafeinat Catalan society might be worse than language death. For Modest Prats, the Catalan language has already divided into the Latin configuration of classical and colloquial varieties. The heart of the linguistic debate remains acceptability: Which Catalan words are tolerable, which are preferred, and which are unacceptable? Jeanne Zang Mier (I984: 192-193) did a study of Catalan linguistic insecurity, in which she compiled a list of what her informants called unacceptable Castilianisms. Eight of the rejected lexemes or expressions were casa meva, amy house", quedar-se "to stay", ovella «sheep", carta «letter», mira «look" (command form), nena "girl», gasolina, "gasoline», and xocar "to hit, to collide with». What all these so-called barbarismes have in common is the fact that they all have clear historic claims to being correct Catalan. Their only defect is in their similarity to Castilian cognates. These false examples of "bad" Catalan illustrate the problem of standards for everyday and literary language use in Catalonia. Purists sometimes reject words that Catalans have used for decades, or at least since the first large-scale linguistic atlases were compiled.

Many public debaters on the normalization issue either follow the «alarmist" philosophy, or the «bandwagon" strategy. The alarmist policy involves amassing all the possible data, whether representative or skewed, to demonstrate the severity of 
Catalan's situation. A Catalan expression referring to this policy might be the crida a fer un debat or the crit d'alarma. The other edge of the policy sword represents the use of statistics and information to show Catalan as a strong viable language. The Linguistic Normalization Office of the Generalitat prefers this strategy. As Miquel Reniu, director of linguistic policy, stated (quoted in Carles, 1990), $90 \%$ of the population understands Catalan, while $64 \%$ can speak it. Among younger people (ages IO-I9), $79 \%$ have oral command of the language. This represents the bandwagon side: Catalan is winning, so get on the bandwagon.

Still, a discussion of linguistic norms and normalization strategies does not address the question of what kind of "Catalan societyn potential recruits would enter. For Guadalupe Rodríguez of the University of Chicago, the integration/segregation model for Catalan society does not take into account the dynamic nature of Catalonia. She claims that many immigrants in the Barcelona suburb where she performed her field study identify themselves primarily as workers, rather than as castellans or catalans. Furthermore, says Rodríguez (personal communication, I990) so few occasions exist for residents of Santa Coloma de Gramenet to improve their passive Catalan skills that recruitment and integration seem improbable goals.

Anthropologist Kathryn Woolard stresses not the linguistic issues, but the overall "crisis in concept of identity" which she perceives in Catalonia (Woolard 1989). For her, the lines are drawn between ethnolinguistic, not just language, groups, and recruitment from one group to another involves more than a change in dominant code.

The most telling evidence about recruitment and defection comes from the informants themselves. Interviewees in the various studies rarely held forth at length about their own identities. As Woolard (1989:40) claims, «People usually did not argue about their identities, they performed them. However, my informants did provide long discussions of when, and with whom, 
and under which conditions, they spoke Catalan or Castilian. The critical age for linguistic recruitment centers around the thirteen-to-sixteen demographic group. No magic aura surrounds this adolescent period; instead, it represents the most propitious time for the "group desirability effect». This is, the strong tendency for members of a group to express opinions and adopt behaviors that are consistent with the goals and philosophy of the group. This is also a common time for transferring from one school to another. Moving a child from a public (possibly Castilian-speaking) school to a private Catalan language institution offers great possibilities for recruitment. The new environment, the relative permeability of adolescent ego boundaries, and the Catalan dominance of the school encourage Catalan use as a socially desirable behavior. Changing schools at age thirteen often permits altering language dominance patterns. ${ }^{T}$

Participation in certain extra-curricular and non-school activities also, fosters recruitment. Woolard stresses the importance of voluntary organizations, such as Girl Scouts, in providing first contacts with Catalan circles. My own research (O'Donnell: $1989,1990)$ demonstrates that involvement in city sponsored activities (popular festivals, local radio stations, youth or sports programs) also creates a favorable environment for combinations of integrative motivations (desire to integrate) and instrumental (practical) impulses for adoption of Catalan.

Still, not everyone will respond favorably to the explicitly Catalanist environment of public organizations or certain volunteer organizations. For example, those who feel that they lose group membership status in one group (their family, their group of paisanos) by joining a Catalan network, may refuse recruitment. Thus, we can discern fertile demographic groups that are more susceptible to recruitment than others. To summarize, re-

${ }^{\text {I }}$ According to Strubell (expected 1990: ro) «most pupils in Barcelona attend private schoolsm. Thus, it is far from uncommon for residents of Catalonia to send their children to non-public schools. 
searchers have found upwardly mobile, goal-oriented, Castilian speakers, who have possibilities for Catalan use outside the home, to be a «fertile» group.

While a number of secondary factors exist that condition linguistic integration (or segregation), recruitment strategy theory does not address the larger questions of who is Catalan, what Catalan is, and what written and spoken Catalan should be. Two opposing approaches to normalization espouse these approximate views: «It doesn't matter whom we recruit, if spoken Catalan becomes so degraded or vulgarized that it continues to merge with Castilian.» The opposing view: «It doesn't matter how pure we make spoken and written Catalan if an increasingly small percentage of Catalonian residents use it. " Since fellow commentators are accused of clear political biases in the policy debate, I shall now admit to the bias underlying the «recruitments project. My research has led me to espouse the second thesis, that of urging non-Catalans to try to speak the language, even if their speech is imperfect. Nevertheless, recruitment must become a two-pronged strategy. The tactics need to take into consideration the views of those those who stress Catalan's tendency toward «dialectization", but also face the realities of Castilian demographic expansion.

One side of the policy coin involves strongly encouraging Castilians to adopt Catalan, even if they incorporate incorrect forms and barbarismes into their speech. The second facet includes establishing reasonable norms for Catalan, and teaching those standards to native speakers and learners of the language. A misapplication of these two policies results in the least desirable strategy: Some Catalans hold would-be recruits to an impossible (and often historically incorrect) linguistic standard. This model includes rejecting the historically correct word carta letter (in favor of the learned missiva, which also has cognates in Castilian and English), and displacing sobre envelope by the Gallicism envelop. For certain Catalan purists, only they (and a few close collaborators) are linguistically and politically «corrects in 
their use of the language. Still, no one would disagree that reasonable, feasible, and historically accurate standards are a requirement for the survival of minority languages.

A normal reaction on the part of a Castilian speaker to the kind of hypercorrection that rejects expressions like casa meva 'my house' might be: «If you can't decide what correct Catalan is, why should I try to speak it?" All sides of the policy debate should agree that this would constitute a failed recruitment policy.

\section{PAUL E. O'DONNELL UNIVERSITY OF MiCHIGAN-FLINT}

\section{BIBLIOGRAPHY}

Consorci d'Informació i Documentació de Catalunya (CIDC) I987. Padrons Municipals d'habitants de Catalunya. I986. Cens lingüístic. Barcelona: CIDC.

CARANCH, Joan Anton. I990. I aleshores el setè àngel va tocar. La Vanguardia (Cultura) July 17, 1990. I1-15.

O'DONNELL, Paul E. I989. A Study of Linguistically «Mixed» Families in Catalonia, Spain: Pluralism and Politics. Romance Languages Annual I. 572-576,

-I990. Recruitment Across Ethnolinguistic Barriers: $\mathrm{Ca}$ talans and castellans. Presented to VIè Col-loqui of the North American Catalan Society, May i990, Vancouver, B. C., Canada.

PASTOR, Carles. I990. «Todas las actividades de este país deberían realizarse en catalán» (Interview with Miquel Reniu, Director general de Política Lingüística, Generalitat de Catalunya). El País. July I3, 1990. 32.

RoDrígueZ, Guadalupe. 1990. Personal communication (phone).

SARRABILE, Graciela. I987. Posibles influencias de la migración 
en los cambios de la fecundidad. Lemsta Española de Investigaciones Sociológicas. 37.

SOBRER, Josep Miquel. 1990. Barcelona Babel. Semiótica 80-3/4. 369-376.

Strubell, Miquel. I990a, Personal communication (mail), based on information from Generalitat de Catalunya (Cultura); Barcelona, Spain.

Strubell, Miquel. r99ob (expected). Barcelona in Mackey, W. et al. The Bilingual City.

Viladot, Albert, 1988. The Social Use of Catalan. Catalònia Culture. 7.29.

WOOLARD, Kathryn A. I989. Double Talk: Bilingualism and the Politics of Ethnicity in Catalonia. Stanford: Stanford University Press.

ZANG MieR, Jeanne. 1984. Catalan: An Atypical Minority Language. Michigan Romance Studies IV. 180-196. 